\title{
Complexes of Dibromo(ethylenediamine)- Palladium(II) Observed from Aqueous Solutions by Electrospray Mass Spectrometry
}

\author{
Stephan B. H. Bach, Tiffanee G. Sepeda, Grant N. Merrill, \\ and Judith A. Walmsley \\ Department of Chemistry, The University of Texas at San Antonio, San Antonio, Texas, USA
}

The dimeric complex of dibromo(ethylenediamine)palladium(II) observed in water was investigated using electrospray mass spectrometry. One $\mu \mathrm{M}$ aqueous solutions of $\mathrm{Pd}(\mathrm{en}) \mathrm{Br}_{2}$ yielded a variety of previously unreported species. The most abundant ion observed was attributable to the $\mathrm{Pd}(\mathrm{en}) \mathrm{Br}_{2} \cdot \mathrm{Pd}(\mathrm{en}) \mathrm{Br}^{+}$dimeric complex at $m / z 568.7$ (most abundant stable isotopes). The characteristics of the oligomeric complexes were examined using collisioninduced dissociation (CID) up to $\mathrm{MS}^{6}$. The most common loss mechanism observed was loss of $\mathrm{HBr}$ leaving an unsaturated $\mathrm{Pd}(\mathrm{II})$ center. Fragmentation of the ethylenediamine ligand was also observed during CID experiments. Loss of Pd was only observed as the final step in the CID process when other loss mechanisms had been exhausted. A number of calculations were carried out at the B3-LYP/SBKJC[d] level of theory in an attempt to elucidate the structure of the $[2 \mathrm{M}-\mathrm{Br}]^{+}$dimer. (J Am Soc Mass Spectrom 2005, 16, 1461-1469) (C) 2005 American Society for Mass Spectrometry

$\mathrm{E}$ xploiting the advantages of electrospray (ES) coupled to trapping mass spectrometers (quadrupole ion trap or Fourier transform ion cyclotron resonance) to investigate the chemistry of aqueous metal ions offers a unique avenue for investigating these complex aqueous chemical systems in detail. This is accomplished by taking advantage of their $\mathrm{MS}^{\mathrm{n}}$ capability [1-4]. Understanding the aqueous chemistry of palladium(II) complexes is of considerable interest because of their interactions with biologically important molecules [5-7] and their use as model systems for $\mathrm{Pt}$ (II) complexes [7-9], four of which, cisplatin, carboplatin, oxaliplatin, and nedaplatin, are currently registered for clinical use [10, 11]. $\mathrm{Pd}(\mathrm{II})$ complexes are also being investigated as possible antitumor agents [12-14]. It is the hydrolytic products of these antitumor complexes that play active roles in their antitumor activity and renal toxicity [15-17]. Because of these facts, the thermodynamic aspects of the hydrolytic reactions of these complexes have previously been the focus of extensive study [14-17] using potentiometry [18-21].

Recently, McFayden [22] and coworkers have investigated the gas-phase mechanisms involved in ligand loss from platinum(II) complexes of tridentate nitrogen donor ligands, such as $\left[\mathrm{Pt}\left(\mathrm{D}_{5} \text { dien }\right) \mathrm{N}\right]^{+}($dien $=$diethylenetriamine), using deuterium labeling. This work was carried out using electrospray and tandem mass spectrometry.

Published online July 18, 2005

Address reprint requests to Dr. S. B. H. Bach, Department of Chemistry, The University of Texas at San Antonio, 6900 North Loop 1604 West, San Antonio, TX 78249-0698, USA. E-mail: Stephan.Bach@utsa.edu
The site of the deprotonation was found to strongly influence the mechanism for $\mathrm{HX}(\mathrm{X}=\mathrm{Cl}, \mathrm{Br}$, I) loss. A series of deuterium studies was undertaken to elucidate the protonation site on the ligand. They observed losses of both DX and HX with the relative ratios depending apparently on $\mathrm{X}$, demonstrating that proton loss can originate from both the amino and the methyl groups. CID experiments undertaken by Schwarz et al. [23] using deuterium substitution have revealed that proton loss in $\mathrm{Ni}(\mathrm{II})$ ethylenediamine arises from one of the amino groups. Previously, McFayden and coworkers [24] investigated the gas-phase fragmentation reactions of ligand substitution products of $\mathrm{Pt}(\mathrm{II})$ complexes. They observed that in most cases collision-induced dissociation (CID) resulted in the loss of $\mathrm{HX}$ giving rise to a coordinatively unsaturated $[\mathrm{Pt}(\mathrm{dien})-\mathrm{H}]^{+}$ion. Both singly- and doublycharged ions of complexes consisting of platinum(II) (ethylenediamine) [25] coordinated to two different substituted pyridines have been observed.

Mass spectrometry has also been used to investigate a variety of platinum and palladium complexes in aqueous/acetonitrile solvent systems. Concentrations ranging from 1 to $100 \mu \mathrm{M}$ are typically employed in these investigations. A variety of monomeric and oligomeric species have been observed. Henderson and Sabat [26], using both electrospray mass spectrometry (ESMS) and nuclear magnetic resonance spectroscopy (NMR), observed only aggregates in the ESMS experiments. Dimers and trimers were observed at low cone voltages $(20 \mathrm{~V})$ for both $\mathrm{Pt}(\mathrm{II})$ and $\mathrm{Pd}(\mathrm{II})$ complexes. As the source collision energy was increased, they reported that the dimers and trimers became less abundant, as 
expected, with the protonated complex predominating. At higher cone voltages ( 40 and $80 \mathrm{~V}$ depending on the complex), the loss of the 2-azetidinone ligand was competitive with protonation in yielding the base peak. In another study, Henderson and Evans [27] observed ionization via loss of the halide ligand. They also studied a bridged $\mathrm{Pd}(\mathrm{I})$ complex $\left[\mathrm{Pd}_{2} \mathrm{Cl}_{2}(\mu \text {-dppm })_{2}\right]$ $\left(\mathrm{dppm}=\mathrm{Ph}_{2} \mathrm{PCH}_{2} \mathrm{PPh}_{2}\right)$ that loses a dppm ligand upon increasing the cone voltage.

Dimers and trimers of platinum(II) containing complexes have also been observed by Sassi et al. [28] for cis- $\left[\mathrm{PtCl}_{2}\left\{E-\mathrm{N}(\mathrm{H})=\mathrm{C}\left(\mathrm{NMe}_{2}\right) \mathrm{Me}_{2}\right]\right.$, and dimers were observed for the similar bis-amidine complex, trans$\left[\mathrm{PtCl}_{2}\left\{\mathrm{E}-\mathrm{N}(\mathrm{H})=\mathrm{C}\left(\mathrm{NMe}_{2}\right) \mathrm{Me}_{2}\right]\right.$. They report that ES is an efficient method for characterizing metal complexes in solution and that these solutions generally produce protonated molecular ions or cationized ions [29]. It is interesting to note that they found that cis and trans compounds generally give rise to different mass spectra.

Ehrsson and coworkers [30] used a triple quadrupole instrument to investigate cisplatin and transplatin as well as their hydrated complexes. They observed both mono- and di-hydrated complexes as well as adducts with $\mathrm{Na}$ and acetonitrile. Fisher et al. [31] investigated the water-soluble $\mathrm{Pt}(\mathrm{TPA})_{3} \mathrm{Cl}_{2}$ [TPA $=1,3,5$-triaza-7phosphaadamantane, $\mathrm{PN}_{3}\left(\mathrm{CH}_{2}\right)_{6}$ ] complex using FTICR. They observed a variety of dimer and trimer complexes in both positive and negative mode. They postulate that the dimers and trimers were attributable to the impact of concentration on the formation of noncovalent clusters. However, if these are noncovalently bound clusters, it would be reasonable to expect losses of the $\mathrm{Pt}(\mathrm{TPA})_{3} \mathrm{Cl}$ subunits rather than just the TPA ligand. They did not, however, observe the loss of $\mathrm{Pt}(\mathrm{TPA})_{3} \mathrm{Cl}$ from the CID of the dimers or trimers. These results seem to indicate a stronger than expected interaction between the metal centers of the clusters or ligand exchange in terms of TPA binding with two metals.

Other investigations have focused on the reactions of Pd(II) complexes with biomolecules. The interaction of palladium(II) complexes with sulfur containing peptides was investigated by $\mathrm{Zhu}$ et al. [32]. The reactive species in this study was $\mathrm{Pd}(\mathrm{en})\left(\mathrm{H}_{2} \mathrm{O}\right)_{2}{ }^{2+}$ rather than $\mathrm{Pd}(\mathrm{en}) \mathrm{Cl}_{2}$. Ralph et al. [33] reported an investigation of the reactions of $\mathrm{Pd}(\mathrm{en}) \mathrm{Cl}_{2}$ with the oligonucleotide 5'-GGCTAGCC-3'. Using negative-ion detection, they observed several trianionic products containing one, two, and three $\mathrm{Pd}(\mathrm{en})^{2+}$ units with the spacing of $\mathrm{m} / \mathrm{z}$ equal to 55 (or $165 \mathrm{Da}$ ). However, they were not able to resolve the isotopic patterns of the product anions to confirm the number of palladiums or to elucidate the structures of the observed CID.

In the present study, we investigate the aqueous chemistry of the dibromo-(ethylenediamine) palladium(II), $\mathrm{Pd}(\mathrm{en}) \mathrm{Br}_{2}$ ([M]) complex at $\mathrm{pH} \approx 4.4$. We present a more detailed CID examination of the oligomeric complexes observed from the dimer. The focus of this work is on the dibromo complex because it offers a clear advantage for distinguishing between the loss of the halide $\left(\mathrm{Br}^{-}\right)$and the possible loss of combinations of the hydroxo and aqua species from the observed complexes. In the case of chlorine, the loss of $\mathrm{Cl}^{-}$or $\mathrm{HCl}$ gives a mass loss (35 or $36 \mathrm{Da}$, respectively) that is essentially indistinguishable from the loss of combinations of $\mathrm{OH}^{-}$and $\left.\mathrm{H}_{2} \mathrm{O}\right] \mathrm{OH}^{-}+\mathrm{H}_{2} \mathrm{O}(35 \mathrm{Da})$, and $2 \mathrm{H}_{2} \mathrm{O}$ (36 Da)]. Since we are investigating an aqueous solution and expect aqueous complexes, this has the potential for creating considerable ambiguity in the possible peak assignments. One $\mu \mathrm{M}$ solutions were chosen as the starting point in this investigation for two reasons. First, dilute solutions are more compatible with ES investigations because they are less likely to produce noncovalently bound clusters. Second, a $1 \mu \mathrm{M}$ solution of $\mathrm{Pd}(\mathrm{en}) \mathrm{Br}_{2}$ at $\mathrm{pH} \approx 4.4$ was expected to yield a single species in solution, $\left[\mathrm{Pd}(\mathrm{en})\left(\mathrm{H}_{2} \mathrm{O}\right)_{2}\right]^{2+}$, from potentiomentirc work at $\mathrm{pH} 4.4[21,34]$.

We observed a number of species in the ES mass spectra that have not been previously reported in solution from the potentiometric studies. Considering that the aqueous solution of the $\mathrm{Pd}(\mathrm{en}) \mathrm{Br}_{2}$ complex is an equilibrium system, the observation of such a large number of species was ascribed to several factors such as ligand exchange in solution and ion-molecule and ion-ion interactions that took place in the solution and during the desolvation process. A number of calculations were carried out at the B3-LYP/SBKJC[d] level of theory in an attempt to elucidate the structure of the $[2 \mathrm{M}-\mathrm{Br}]^{+}$dimer.

\section{Experimental}

\section{Materials}

$\mathrm{K}_{2} \mathrm{PdBr}_{4}$ and 1,2-diaminoethane (ethylenediamine, en) were purchased from Aldrich (Milwaukee, WI). $\mathrm{HBr}$ $(48 \%)$ was purchased from Fisher Scientific (Houston, $\mathrm{TX}$ ), and deionized water (DI, $18 \mathrm{M} \Omega$ ) was obtained using a Barnstead Nanopure system (Dubuque, IA). IR spectra were run on a Bruker Vector 20 FTIR (Bruker Optics, Billerica, MA) using a Golden Gate Diamond ATR (Specac, Woodstock, GA) attachment. Elemental analyses were run by Midwest Microlab (Indianapolis, IN).

\section{Synthesis of $\mathrm{Pd}(\mathrm{en}) \mathrm{Br}_{2}$}

$\mathrm{Pd}(\mathrm{en}) \mathrm{Br}_{2}$ was prepared by modification of a method for the synthesis of $\mathrm{Pd}(\mathrm{en}) \mathrm{Cl}_{2}$ [35]. $\mathrm{K}_{2} \mathrm{PdBr}_{4}(0.500 \mathrm{~g})$ was dissolved in $4.0 \mathrm{ml}$ of warm water, and the resulting solution was divided into two equal portions. To one of the portions in a glass vial, $1.05 \mathrm{ml}$ of $1.5 \mathrm{M}$ of an aqueous ethylenediamine solution was added dropwise while stirring. The resulting mixture was boiled for $1.5 \mathrm{~h}$ while the volume was maintained at $\sim 3 \mathrm{ml}$ by addition of deionized water. At the end of the heating, all of the precipitate was dissolved. The solution was cooled to $10{ }^{\circ} \mathrm{C}$ in an ice bath. To the cooled solution, the remaining $2 \mathrm{ml}$ portion of the $\mathrm{K}_{2} \mathrm{PdBr}_{4}$ solution was 
added slowly while stirring. The voluminous orangecolored precipitate was separated by vacuum filtration and washed with several $1 \mathrm{ml}$ portions of deionized water. The precipitate was suspended in $6.0 \mathrm{ml}$ of deionized water containing two drops of $6 \mathrm{M} \mathrm{HBr}$, and the mixture was evaporated to $\sim 1 \mathrm{ml}$. The suspension and reconcentration steps were repeated two more times, resulting in a gold-colored precipitate. The mixture was cooled in an ice bath and filtered. The golden crystals were washed with several portions of cold deionized water, air-dried, and placed in a dessiccator overnight. An IR of the solid was obtained. The compound (av. mol. wt. $326.34 \mathrm{Da}$ ) did not melt, but decomposed above $256{ }^{\circ} \mathrm{C}$. Elemental analysis: obs., (theor), \% C 7.56 (7.36); \% H 2.40 (2.47); \% N 8.47 (8.59); $\%$ Br 48.85 (48.97).

\section{$\mathrm{Pd}(\mathrm{en}) \mathrm{Br}_{2}$ Stock Solution}

The stock solution was prepared by dissolving $3.3 \mathrm{mg}$ of $\operatorname{Pd}(\mathrm{en}) \mathrm{Br}_{2}(1 \mathrm{mmol})$ in $10.0 \mathrm{ml}$ of deionized water in a clean, dry glass vial. The vial was capped and warmed slightly for two days to dissolve the solid. This yielded a $1.0 \mathrm{mM}$ solution of $\mathrm{pH} 4.4$.

\section{Mass Spectrometric Analysis}

The aqueous solutions of palladium complexes were investigated using a Finnigan LCQ Duo (Thermo Finnigan, San Jose, CA) quadrupole ion trap mass spectrometer using electrospray. All data were collected and analyzed using the Xcalibur software (Thermo Finnigan) in full scan and MS/MS mode. The LCQ Duo was tuned with a 2.5 pmol solution of angiotensin I using the triply charged peak at $\mathrm{m} / \mathrm{z}$ 433.2. The relative collision energy used for CID was uncalibrated and in arbitrary units. Normalized collision energies (NCE) between 10 and $30 \%$ were used. The MS conditions routinely used were: source voltage, $4.5 \mathrm{kV}$; capillary temperature, $180^{\circ} \mathrm{C}$; capillary voltage, $10.5 \mathrm{~V}$; sheath gas flow rate, 45 (arbitrary units), and the auxiliary gas flow rate, 4 (arbitrary units). Solutions were introduced by flow injection at a rate of $5 \mu \mathrm{L} / \mathrm{min}$.

Simulations of the stable isotope patterns were made using Isotope Viewer in Xcalibur. For the simulated mass spectra, the default settings were used unless otherwise noted: resolution, $1 \mathrm{Da}$ at $5 \%$ height and a +1 charge.

\section{Computational Methods}

The B3-LYP hybrid density functional [36] was employed in all the computations. All core electrons were treated with Stevens, Basch, Krauss, Jasien, and Cundari (SBKJC) effective core potentials (ECP) [37-39], while the valence electrons were modeled with the SBKJC double-split valence basis set to which a single set of d-type polarization functions [40] were added to all atoms except hydrogen and palladium. All struc-

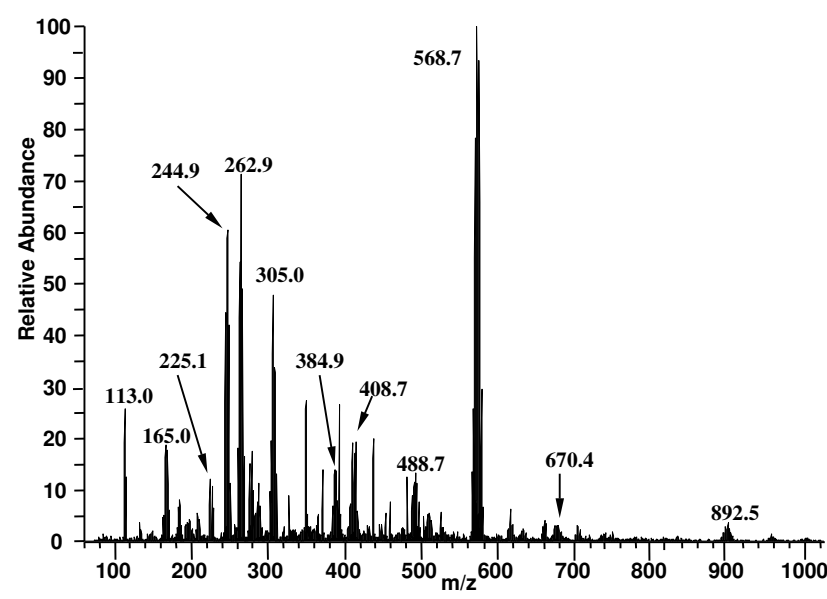

Figure 1. Positive ion mass spectrum of an aqueous solution of $\operatorname{Pd}(\mathrm{en}) \mathrm{Br}_{2}, 1 \mu \mathrm{M}, \mathrm{pH} \approx 4.4$.

tures were fully optimized, and their associated Hessian matrices were determined. The Hessian matrices allowed for the structures to be verified as minimum-energy structures. All calculations were carried out with the GAMESS program [41] running on a Beowulf cluster of personal computers at the University of Texas Health Science Center at San Antonio (UTHSCSA).

\section{Results}

Complexes that contain one or more palladium atoms are fairly straightforward to distinguish by mass spectrometry because of the seven naturally occurring stable isotopes of palladium that have significant natural abundances. The stable isotopes for palladium range from 101.9 $\mathrm{Da}(1 \%$ natural abundance) to $109.9 \mathrm{Da}(11.7 \%)$ with the most abundant at $105.9 \mathrm{Da}(27.3 \%)$. The masses reported in this paper for each of the complexes will be the mass containing the most abundant stable isotope of each element in the complex. For example, the mass for $\mathrm{Pd}(\mathrm{en}) \mathrm{Br}_{2}([\mathrm{M}])$ will be reported at $m / z$ 323.8.

Figure 1 shows the positive ion mass spectrum acquired from a $1 \mu \mathrm{M}$ aqueous solution of $\mathrm{Pd}(\mathrm{en}) \mathrm{Br}_{2}$ $(\mathrm{pH} \approx 4.4)$. No significant peaks were observed above $\mathrm{m} / \mathrm{z} 1100$ or below $\mathrm{m} / \mathrm{z} 100$. Typical mass spectra consisted of peaks that corresponded to monomeric, dimeric, and trimeric species. The base peak in the mass spectrum at $\mathrm{m} / \mathrm{z} 568.7$ was interpreted as the dimeric species $\left(\mathrm{Pd}(\mathrm{en}) \mathrm{Br}_{2}\right) \cdot \operatorname{Pd}(\mathrm{en}) \mathrm{Br}^{+}\left([2 \mathrm{M}-\mathrm{Br}]^{+}\right)$. The overall +1 charge for the complex is the result of the loss of a bromide ion. A weak set of peaks was observed at $m / z 670.4$ and has been assigned to the sodium adduct of the dimer $\left[2 \mathrm{M}+\mathrm{Na}^{+}\right.$. The trimeric complex, $[3 \mathrm{M}-$ $\mathrm{Br}]^{+}$, was observed in most of the spectra at $\mathrm{m} / \mathrm{z}$ 892.5. A very weak set of peaks at $\mathrm{m} / \mathrm{z} 1000$ has been observed in some spectra and assigned to $[3 \mathrm{M}+\mathrm{Na}]^{+}$. A list of the complexes observed in a typical mass spectrum and their relative intensities can be found in Table 1 .

Figure $2 \mathrm{a}$ shows the region around $[2 \mathrm{M}-\mathrm{Br}]^{+}$ 
Table 1. ESMS and $\mathrm{MS}^{\mathrm{n}}$ ions observed from an aqueous $1 \mu \mathrm{M}$ solution of $\mathrm{Pd}(\mathrm{en}) \mathrm{Br}_{2}$ at $\mathrm{pH} \approx 4.4$

\begin{tabular}{|c|c|}
\hline & Principle lons Observed $(\mathrm{m} / \mathrm{z}, \%)$ \\
\hline $\mathrm{d}(\mathrm{en}) \mathrm{Br}_{2} @ \mathrm{pH} \approx 4.4$ & $\begin{array}{l}{[3 \mathrm{M}-\mathrm{Br}]^{+}(892.5,5 \%),[2 \mathrm{M}+\mathrm{Na}]^{+}(670.4,5 \%),[2 \mathrm{M}-\mathrm{Br}]^{+}(568.7,100 \%),} \\
{[2 \mathrm{M}-\mathrm{HBr}-\mathrm{Br}]^{+}(488.7,15 \%),[2 \mathrm{M}-2 \mathrm{HBr}-\mathrm{Br}]^{+}(408.7,20 \%),[\mathrm{M}+\mathrm{en}+} \\
\mathrm{H}]^{+}(384.9,15 \%),[\mathrm{M}+\mathrm{en}-\mathrm{Br}]^{+}(305.0,45 \%),\left[\mathrm{M}+\mathrm{H}_{2} \mathrm{O}-\mathrm{Br}\right]^{+}(262.9, \\
\quad 70 \%),[\mathrm{M}-\mathrm{Br}]^{+}(244.9,60 \%),[\mathrm{M}+\mathrm{en}-\mathrm{H}-2 \mathrm{Br}]^{+}(225.1,10 \%),[\mathrm{M}-\mathrm{HBr} \\
-\mathrm{Br}]^{+}(165.0,20 \%),[\mathrm{M}+\mathrm{en}-2 \mathrm{Br}]^{2+}(113.0,25 \%)\end{array}$ \\
\hline \multicolumn{2}{|l|}{ MS/MS Experiments } \\
\hline $\mathrm{CID}$ of $[3 \mathrm{M}-\mathrm{Br}]^{+} @ 15 \%$ & {$[3 \mathrm{M}-\mathrm{Br}]^{+}(892.5,100 \%),[2 \mathrm{M}-\mathrm{Br}]^{+}(568.7,40 \%)$} \\
\hline $\mathrm{CID}$ of $[3 \mathrm{M}-\mathrm{Br}]^{+} @ 20 \%$ & {$[3 \mathrm{M}-\mathrm{Br}]^{+}(892.5,60 \%),[2 \mathrm{M}-\mathrm{Br}]^{+}(568.7,100 \%)$} \\
\hline ID of $[2 \mathrm{M}-\mathrm{Br}]^{+} @ 10 \%$ & {$[2 \mathrm{M}-\mathrm{Br}]^{+}(568.7,100 \%)$} \\
\hline $\mathrm{CID}$ of $[2 \mathrm{M}-\mathrm{Br}]^{+} @ 20 \%$ & {$[2 \mathrm{M}-\mathrm{Br}]^{+}(568.7,100 \%)$, all other ions below $10 \%$} \\
\hline $\mathrm{CID}$ of $[2 \mathrm{M}-\mathrm{Br}]^{+} @ 25 \%$ & $\begin{array}{l}{[2 \mathrm{M}-\mathrm{Br}]^{+}(568.7,100 \%),[2 \mathrm{M}-\mathrm{HBr}-\mathrm{Br}]^{+}(488.7,90 \%),\left[2 \mathrm{M}-\mathrm{HBr}-\mathrm{NH}_{3}-\right.} \\
\mathrm{Br}]^{+}(471.7,35 \%),[2 \mathrm{M}-2 \mathrm{HBr}-\mathrm{Br}]^{+}(408.7,90 \%),\left[2 \mathrm{M}-2 \mathrm{HBr}-\mathrm{NH}_{3}-\right. \\
\mathrm{Br}]^{+}(391.7,20 \%)\end{array}$ \\
\hline $\mathrm{CID}$ of $[2 \mathrm{M}-\mathrm{Br}]^{+} @ 30 \%$ & $\begin{array}{l}{[2 \mathrm{M}-\mathrm{Br}]^{+}(568.7,30 \%),[2 \mathrm{M}-\mathrm{HBr}-\mathrm{Br}]^{+}(488.7,65 \%),\left[2 \mathrm{M}-\mathrm{HBr}-\mathrm{NH}_{3}-\right.} \\
\mathrm{Br}]^{+}(471.7,30 \%),[2 \mathrm{M}-2 \mathrm{HBr}-\mathrm{Br}]^{+}(408.7,100 \%),\left[2 \mathrm{M}-2 \mathrm{HBr}-\mathrm{NH}_{3}-\right. \\
\quad \mathrm{Br}]^{+}(391.7,20 \%)\end{array}$ \\
\hline \multicolumn{2}{|l|}{$\mathrm{MS}^{3}$ Experiments } \\
\hline $\begin{array}{l}\mathrm{CID} \text { of }[2 \mathrm{M}-\mathrm{Br}]^{+} @ 30 \% \text { and of }[2 \mathrm{M}-\mathrm{HBr} \\
-\mathrm{Br}]^{+} @ 25 \%\end{array}$ & $\begin{array}{c}{[2 \mathrm{M}-\mathrm{HBr}-\mathrm{Br}]^{+}(488.7,5 \%),\left[2 \mathrm{M}-\mathrm{HBr}-\mathrm{NH}_{3}-\mathrm{Br}\right]^{+}(471.7,30 \%),[2 \mathrm{M}-} \\
2 \mathrm{HBr}-\mathrm{Br}]^{+}(408.7,100 \%),\left[2 \mathrm{M}-2 \mathrm{HBr}-\mathrm{NH}_{3}-\mathrm{Br}\right]^{+}(391.7,20 \%)\end{array}$ \\
\hline $\begin{array}{l}\mathrm{CID} \text { of }[2 \mathrm{M}-\mathrm{Br}]^{+} @ 30 \% \text { and of }[2 \mathrm{M}- \\
2 \mathrm{HBr}-\mathrm{Br}]^{+} @ 10 \%\end{array}$ & {$[2 \mathrm{M}-2 \mathrm{HBr}-\mathrm{Br}]^{+}(408.7,100 \%)$} \\
\hline $\begin{array}{l}\mathrm{CID} \text { of }[2 \mathrm{M}-\mathrm{Br}]^{+} @ 30 \% \text { and of }[2 \mathrm{M}- \\
2 \mathrm{HBr}-\mathrm{Br}]^{+} @ 25 \%\end{array}$ & {$[2 \mathrm{M}-2 \mathrm{HBr}-\mathrm{Br}]^{+}(408.7,100 \%),[2 \mathrm{M}-3 \mathrm{HBr}-\mathrm{Br}]^{+}(328.7,55 \%)$} \\
\hline \multicolumn{2}{|l|}{$\mathrm{MS}^{4}$ Experiments } \\
\hline $\begin{array}{l}\mathrm{CID} \text { of }[2 \mathrm{M}-\mathrm{Br}]^{+} @ 30 \% \text {, of }[2 \mathrm{M}-\mathrm{HBr}- \\
\mathrm{Br}]^{+} @ 25 \% \text { and of }[2 \mathrm{M}-2 \mathrm{HBr}-\mathrm{Br}]^{+} @ \\
15 \%\end{array}$ & {$[2 \mathrm{M}-2 \mathrm{HBr}-\mathrm{Br}]^{+}(408.7,100 \%)$} \\
\hline $\begin{array}{l}\mathrm{CID} \text { of }[2 \mathrm{M}-\mathrm{Br}]^{+} @ 30 \% \text {, of }[2 \mathrm{M}-\mathrm{HBr}- \\
\mathrm{Br}]^{+} @ 25 \% \text { and of }[2 \mathrm{M}-2 \mathrm{HBr}-\mathrm{Br}]^{+} @ \\
25 \%\end{array}$ & $\begin{array}{c}{[2 \mathrm{M}-2 \mathrm{HBr}-\mathrm{Br}]^{+}(408.7,80 \%),[2 \mathrm{M}-3 \mathrm{HBr}-\mathrm{Br}]^{+}(328.7,100 \%),[2 \mathrm{M}---} \\
\quad \mathrm{H}-2 \mathrm{HBr}-\mathrm{Br}]^{+}(349.7,20 \%),\left[2 \mathrm{M}-\mathrm{CH}_{4} \mathrm{~N}-2 \mathrm{HBr}-\mathrm{Br}\right]^{+}(378.7,20 \%)\end{array}$ \\
\hline $\begin{array}{l}\mathrm{CID} \text { of }[2 \mathrm{M}-\mathrm{Br}]^{+} @ 30 \% \text {, of }[2 \mathrm{M}-\mathrm{HBr}- \\
\mathrm{Br}]^{+} @ 25 \% \text { and of }\left[2 \mathrm{M}-2 \mathrm{HBr}-\mathrm{NH}_{3}-\right. \\
\mathrm{Br}]^{+} @ 30 \%\end{array}$ & $\begin{array}{l}{\left[2 \mathrm{M}-2 \mathrm{HBr}-\mathrm{NH}_{3}-\mathrm{Br}\right]^{+}(391.7,20 \%),\left[2 \mathrm{M}-\mathrm{C}_{2} \mathrm{H}_{3}-2 \mathrm{HBr}-\mathrm{NH}_{3}-\mathrm{Br}\right]^{+}} \\
\quad(364.7,15 \%),\left[2 \mathrm{M}-\mathrm{C}_{2} \mathrm{H}_{4} \mathrm{~N}-2 \mathrm{HBr}-\mathrm{NH}_{3}-\mathrm{Br}\right]^{+}(349.7,100 \%)\end{array}$ \\
\hline \multicolumn{2}{|l|}{$\mathrm{MS}^{5}$ Experiments } \\
\hline $\begin{array}{l}\mathrm{CID} \text { of }[2 \mathrm{M}-\mathrm{Br}]^{+} @ 25 \% \text {, of }[2 \mathrm{M}-\mathrm{HBr}- \\
\mathrm{Br}]^{+} @ 30 \%, \text { of }[2 \mathrm{M}-2 \mathrm{HBr}-\mathrm{Br}]^{+} @ 30 \\
\% \text { and of }[2 \mathrm{M}-3 \mathrm{HBr}-\mathrm{Br}]^{+} @ 20 \%\end{array}$ & $\begin{array}{l}{[2 \mathrm{M}-3 \mathrm{HBr}-\mathrm{Br}]^{+}(328.7,80 \%),\left[\left[2 \mathrm{M}-\mathrm{NH}_{3}-3 \mathrm{HBr}-\mathrm{Br}\right]^{+}(312.9,80 \%),[2 \mathrm{M}\right.} \\
\left.\quad-\mathrm{CH}_{4} \mathrm{~N}-3 \mathrm{HBr}-\mathrm{Br}\right]^{+}(298.9,100 \%)\end{array}$ \\
\hline $\begin{array}{l}\mathrm{CID} \text { of }[2 \mathrm{M}-\mathrm{Br}]^{+} @ 25 \% \text {, of }[2 \mathrm{M}-\mathrm{HBr}- \\
\mathrm{Br}]^{+} @ 30 \%, \text { of }[2 \mathrm{M}-2 \mathrm{HBr}-\mathrm{Br}]^{+} @ 30 \\
\% \text { and of }[2 \mathrm{M}-3 \mathrm{HBr}-\mathrm{Br}]^{+} @ 30 \%\end{array}$ & $\begin{array}{l}{[2 \mathrm{M}-3 \mathrm{HBr}-\mathrm{Br}]^{+}(328.7,15 \%),\left[\left[2 \mathrm{M}-\mathrm{NH}_{3}-3 \mathrm{HBr}-\mathrm{Br}\right]^{+}(312.9,40 \%),[2 \mathrm{M}\right.} \\
\left.\quad-\mathrm{CH}_{4} \mathrm{~N}-3 \mathrm{HBr}-\mathrm{Br}\right]^{+}(298.9,100 \%)\end{array}$ \\
\hline $\begin{array}{l}\text { CID of }[2 \mathrm{M}-\mathrm{Br}]^{+} @ 25 \% \text {, of }[2 \mathrm{M}-\mathrm{HBr}- \\
\mathrm{Br}]^{+} @ 30 \% \text { of }\left[2 \mathrm{M}-2 \mathrm{HBr}-\mathrm{NH}_{3}-\mathrm{Br}\right]^{+} \\
@ 30 \% \text { and of }\left[2 \mathrm{M}-\mathrm{C}_{2} \mathrm{H}_{3} \mathrm{NH}-2 \mathrm{HBr}-\right. \\
\left.\mathrm{NH}_{3}-\mathrm{Br}\right]^{+} @ 25 \%\end{array}$ & $\begin{array}{l}{\left[2 \mathrm{M}-\mathrm{C}_{2} \mathrm{H}_{4} \mathrm{~N}-2 \mathrm{HBr}-\mathrm{NH}_{3}-\mathrm{Br}^{+}(349.7,100 \%),\left[2 \mathrm{M}-\mathrm{C}_{2} \mathrm{H}_{4} \mathrm{~N}-3 \mathrm{HBr}-\right.\right.} \\
\left.\mathrm{NH}_{3}-\mathrm{Br}\right]^{+}(269.7,40 \%),\left[2 \mathrm{M}-\mathrm{C}_{2} \mathrm{H}_{4} \mathrm{~N}-2 \mathrm{HBr}-\mathrm{NH}_{2}-\mathrm{NH}_{3}-\mathrm{Br}\right]^{+}(333.7 \\
25 \%),\left[2 \mathrm{M}-\mathrm{C}_{2} \mathrm{H}_{4} \mathrm{~N}-3 \mathrm{HBr}-\mathrm{NH}_{3}-\mathrm{Pd}-\mathrm{Br}\right]^{+}(165.0,15 \%)\end{array}$ \\
\hline $\begin{array}{l}\mathrm{MS}^{6} \text { Experiments } \\
\mathrm{CID} \text { of }[2 \mathrm{M}-\mathrm{Br}]^{+} @ 25 \% \text {, of }[2 \mathrm{M}-\mathrm{HBr}- \\
\mathrm{Br}]^{+} @ 30 \%, \text { of }[2 \mathrm{M}-2 \mathrm{HBr}-\mathrm{Br}]^{+} @ 30 \\
\%, \text { of }[2 \mathrm{M}-3 \mathrm{HBr}-\mathrm{Br}]^{+} @ 30 \%[2 \mathrm{M}- \\
\left.\mathrm{CH}_{4} \mathrm{~N}-3 \mathrm{HBr}-\mathrm{Br}\right]^{+} @ 25 \%\end{array}$ & $\begin{array}{l}{\left[2 \mathrm{M}-\mathrm{CH}_{4} \mathrm{~N}-3 \mathrm{HBr}-\mathrm{Br}\right]^{+}(298.9,60 \%),\left[2 \mathrm{M}-\mathrm{CH}_{4} \mathrm{~N}-\mathrm{CH}_{3} \mathrm{~N}-3 \mathrm{HBr}-\mathrm{Br}\right]^{+}} \\
\quad(269.7,100 \%),\left[2 \mathrm{M}-\mathrm{CH}_{4} \mathrm{~N}-3 \mathrm{HBr}-\mathrm{Pd}-\mathrm{Br}\right]^{+}(192.8,10 \%)\end{array}$ \\
\hline
\end{tabular}

expanded to reveal the isotopic detail. The simulated mass spectrum of the $[2 \mathrm{M}-\mathrm{Br}]^{+}$is shown in Figure $2 \mathrm{~b}$. As can be seen, there is excellent agreement between the experimentally observed and the simulated isotopic distribution patterns. This type of close agreement between observed and simulated mass spectra was true for all of the assigned complexes, giving us confidence in the assigned molecular formulas.

Two other dimeric complexes were also observed
(Figure 1) resulting from the loss of $\mathrm{HBr}$. The dimeric complex $[2 \mathrm{M}-\mathrm{HBr}-\mathrm{Br}]^{+}$at $m / z 488.7$ is the result of the loss of one $\mathrm{HBr}$ from $[2 \mathrm{M}-\mathrm{Br}]^{+}$. The dimeric complex $[2 \mathrm{M}-2 \mathrm{HBr}-\mathrm{Br}]^{+}$at $m / z 408.7$ is the result of a further loss of $\mathrm{HBr}$ from $[2 \mathrm{M}-\mathrm{HBr}-\mathrm{Br}]^{+}$.

There were several other complexes observed in the full mass spectrum (Figure 1) that have been identified. A doubly charged complex, $\mathrm{Pd}(\mathrm{en})_{2}{ }^{2+}$, is observed with a $\mathrm{Pd}$ isotopic pattern around $m / z 113.0$ and is due to 

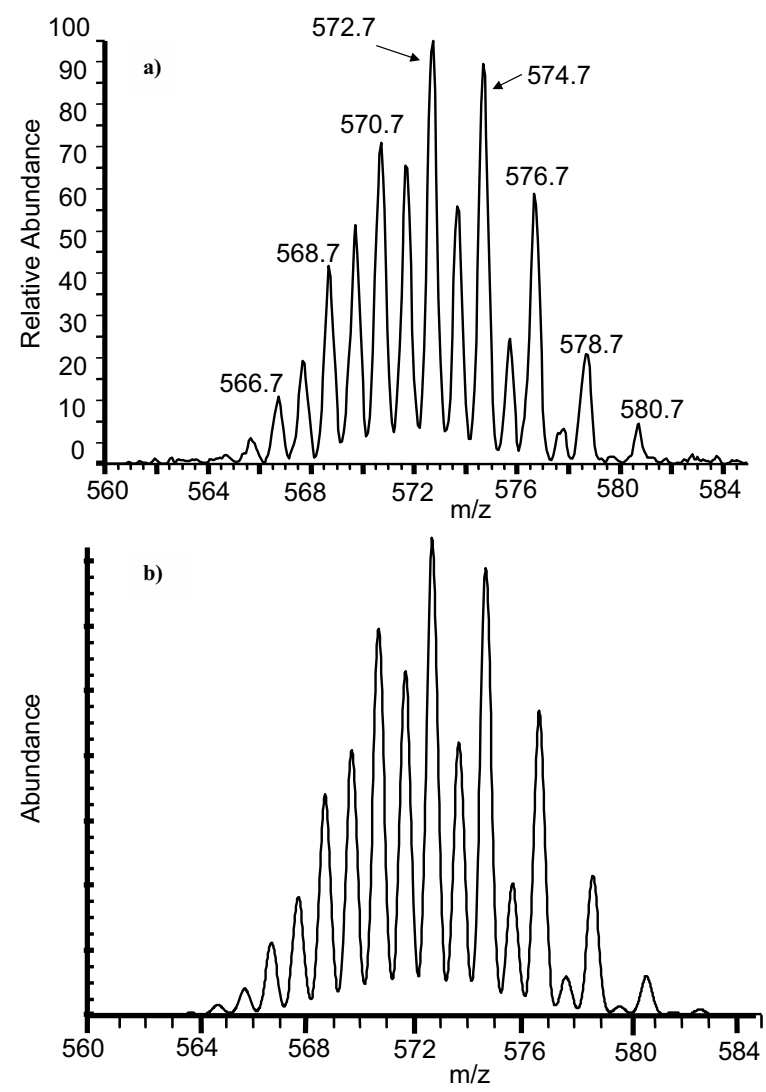

Figure 2. (a) Expanded region of the $\mathrm{Pd}(\mathrm{en}) \mathrm{Br}_{2} \cdot \mathrm{Pd}(\mathrm{en}) \mathrm{Br}^{+}$ complex from a full scan of a $1 \mu \mathrm{M} \mathrm{Pd}(\mathrm{en}) \mathrm{Br}_{2}$ aqueous solution at $\mathrm{pH} \approx 4.4 ;$ (b) simulated mass spectrum of the $\mathrm{Pd}(\mathrm{en}) \mathrm{Br}_{2}$. $\mathrm{Pd}(\mathrm{en}) \mathrm{Br}^{+}$complex using the Isotope Viewer in Xcalibur.

ligand exchange. From the observed isotopic pattern clearly the molecule contains a single palladium and no bromine. The 0.5 unit spacing of the observed peaks is evidence that the complex is a dication. A series of monomeric complexes were found between $\mathrm{m} / \mathrm{z} 220$ and 320. These peaks are assigned to the following species: $\mathrm{Pd}(\mathrm{en})(\mathrm{en}-\mathrm{H})^{+}[\mathrm{M}+\text { en }-\mathrm{H}-2 \mathrm{Br}]^{+}$at $\mathrm{m} / \mathrm{z} 225.1$; $\mathrm{Pd}(\mathrm{en}) \mathrm{Br}^{+}[\mathrm{M}-\mathrm{Br}]^{+}$at $m / z$ 244.9; $\mathrm{Pd}(\mathrm{en})\left(\mathrm{H}_{2} \mathrm{O}\right) \mathrm{Br}^{+}[\mathrm{M}$ $\left.+\mathrm{H}_{2} \mathrm{O}-\mathrm{Br}\right]^{+}$at $\mathrm{m} / \mathrm{z} 262.9$, which is the only aqua species observed; and $\mathrm{Pd}(\mathrm{en})_{2} \mathrm{Br}^{+}[\mathrm{M}+\mathrm{en}-\mathrm{Br}]^{+}$at $\mathrm{m} / \mathrm{z}$ 305.0. The observed isotopic distribution patterns readily reveal which of these complexes contains a single bromine, thereby enabling the complex to be singly charged without a change in the oxidation state of Pd. The isotopic pattern for $\mathrm{Pd}(\mathrm{en})(\mathrm{en}-\mathrm{H})$ at $\mathrm{m} / \mathrm{z} 225$ is that for a complex that contains only a single Pd and no Br. This complex is of particular interest as a proton has been lost from en. Another set of peaks at $\mathrm{m} / \mathrm{z} 165.0$ was also observed in Figure 1. Again, from the isotopic pattern and mass, one can discern that the observed species contains only a single $\mathrm{Pd}$, no $\mathrm{Br}$, and has a +1 charge. It is interesting to note that this complex differs from the mass of the $\mathrm{Pd}(\mathrm{en})(\mathrm{en}-\mathrm{H})^{+}$complex by an ethylenediamine unit and, therefore, has been assigned to $\mathrm{Pd}(\mathrm{en}-\mathrm{H})^{+}[\mathrm{M}-\mathrm{H}-2 \mathrm{Br}]^{+}$. The only protonated $\mathrm{Pd}$ complex observed was $\mathrm{Pd}(\mathrm{en})_{2} \mathrm{Br}_{2} 52>\mathrm{H}^{+}[\mathrm{M}+$ en + $\mathrm{H}^{+}$at $m / z 384.9$.

\section{Collision-Induced Dissociation Experiments}

A series of collision-induced dissociation (CID) experiments was undertaken to elucidate the structure and stability of the $[2 \mathrm{M}-\mathrm{Br}]^{+}$dimer. A parent mass isolation width of between 10 and $20 \mathrm{~m} / z$ was used so as to include the full isotope pattern for the dimer. The isolation of each of the parent masses was checked using a NCE of $10 \%$ to verify that only the parent ion was present. The results from the various $\mathrm{MS}^{\mathrm{n}}$ experiments are summarized in Table $1 . \mathrm{MS}^{2}$ to $\mathrm{MS}^{6}$ experiments were undertaken to further elucidate the structure of dimer. The goal here was to gain insights into the strength and stability of the dimer complex.

Information regarding the substructure of a complex can be determined using CID if the precursor ion is significantly abundant to perform multiple MS/MS (or $M^{n}$ ) experiments on successive fragments. This will eventually reveal the core of the dimer complex. For a weakly bound complex, it should be expected that the dimer will break apart into its monomer subunits during the initial MS/MS experiment. If some type of bonding is present between the monomer subunits, giving strength and stability to the structure of the dimer complex, there might be sufficient interaction between the monomeric bonds for both metal centers to be part of the smallest fragment observed from the $\mathrm{MS}^{\mathrm{n}}$ experiments. Table 1 presents a summary of the precursor ions used for each of the $\mathrm{MS}^{\mathrm{n}}$ experiments and the product ions observed along with associated neutral losses. While the unambiguous assignment of structures to the CID products is sometimes difficult because of the low signal intensity after some of the CID steps, the proposed structures fit well in the overall scheme and are supported by the mass spectrometric data. Figure 3 presents a schematic that summarizes the observed relationships between the various product ions in the $\mathrm{MS}^{\mathrm{n}}$ experiments.

Even though the trimer complex $[3 \mathrm{M}-\mathrm{Br}]^{+}$at $\mathrm{m} / \mathrm{z}$ 892.2 was detected at a very low relative abundance, CID was conducted to gain information about the strength of the interaction between the individual monomer units of the trimer and confirm the noncovalent/covalent nature of the trimer. In this case the loss of a neutral $[\mathrm{M}]$ from the trimer was inferred from the observation of the dimer at $\mathrm{m} / z 568.7[2 \mathrm{M}-\mathrm{Br}]^{+}$. Even with the use of a low NCE of $10 \%$ resulted in [2M $\mathrm{Br}]^{+}$being observed. This clearly indicates that $[3 \mathrm{M}-$ $\mathrm{Br}]^{+}$is not a strongly bound species. The trimer species is most likely a noncovalently bound complex.

\section{Computational}

A number of calculations were carried out at the B3-LYP/SBKJC[d] level of theory in an attempt to elucidate the structure of the $[2 \mathrm{M}-\mathrm{Br}]^{+}$dimer. Given the variety of monomeric cations revealed in the ESMS experiments, a series of possible structures was investigated for the dimer. The lowest energy structure is 


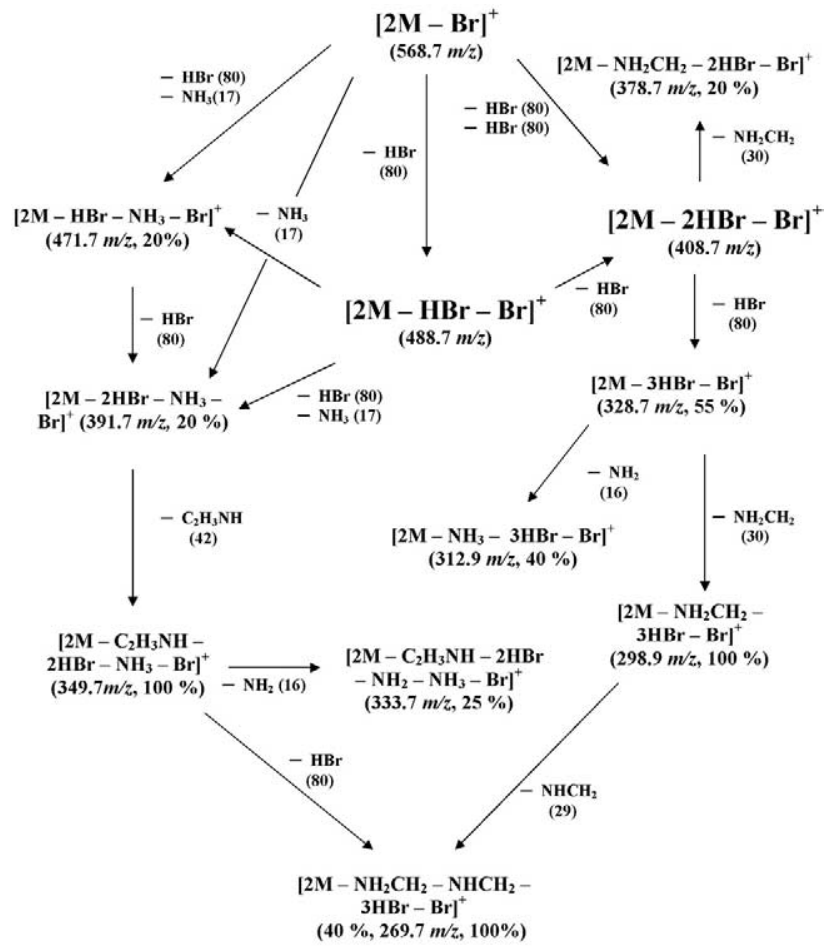

Figure 3. Diagram of the $\mathrm{MS}^{\mathrm{n}}$ experiments and the CID results observed for the $[2 \mathrm{M}-\mathrm{Br}]^{+}$dimer. Ions observed in the full mass spectrum are in large print with no $\%$ intensity. Product ions are listed with \% intensity.

shown in Figure 4. It is predicted to have $C_{2}$ symmetry and possess a single bromide bridge between the palladium atoms. The geometry surrounding the palladium atoms is four-coordinate and roughly squareplanar. The bond distance between the Pd atoms and the bridging $\mathrm{Br}$ atom was found to be $2.54 \AA$, while the analogous distances between the $\mathrm{Pd}$ atoms and nonbridging $\mathrm{Br}$ atoms was found to be $2.45 \AA$. The en ligands form bonds of 2.06 and $2.10 \AA$ between the nitrogen atoms and palladium atoms.

\section{Discussion}

The focus of this paper is the investigation of the [2M $\mathrm{Br}]^{+}$dimeric complex observed as the most abundant ionic species from $1 \mu \mathrm{M}$ aqueous $\mathrm{Pd}(\mathrm{en}) \mathrm{Br}_{2}$ solutions. Other ionic species in the full mass spectrum of the $\mathrm{Pd}(\mathrm{en}) \mathrm{Br}_{2}$ solution are also observed and related to the aqueous chemistry of $\mathrm{Pd}(\mathrm{en}) \mathrm{Br}_{2}$. We have found two types of multimeric species-dimers and trimers. A distinct difference in the behavior is observed between the trimeric and the dimeric species under CID. The only observed neutral loss from $[3 \mathrm{M}-\mathrm{Br}]^{+}$is that of a $\mathrm{Pd}(\mathrm{en}) \mathrm{Br}_{2}$ monomer unit producing $[2 \mathrm{M}-\mathrm{Br}]^{+}$. Also, from the CID experiment, it is apparent that $[3 \mathrm{M}-\mathrm{Br}]^{+}$ is not very strongly bound compared with the dimer. The dimer was observed using only $10 \%$ NCE on [3M $\mathrm{Br}]^{+}$. This setting is typically used to verify a good isolation and does not normally result in fragments being observed. [3M $-\mathrm{Br}]^{+}$was completely fragmented using a NCE of $20 \%$, leaving only $[2 \mathrm{M}-\mathrm{Br}]^{+}$. This is the behavior expected of a noncovalently bound adduct produced by the electrospray process.

The CID of $[2 \mathrm{M}-\mathrm{Br}]^{+}$did not produce the monomer $\mathrm{Pd}(\mathrm{en}) \mathrm{Br}^{+}$, which would be the expected result if the complex were a noncovalently bound cluster. Instead, the CID of $[2 \mathrm{M}-\mathrm{Br}]^{+}$resulted in the sequential loss of two $\mathrm{HBr}$ molecules as well as the loss of $\mathrm{NH}_{3}$ (Table 1). The strength of interaction between the $\mathrm{Pd}(\mathrm{en}) \mathrm{Br}_{2}$ and the $\mathrm{Pd}(\mathrm{en}) \mathrm{Br}^{+}$subunits of $[2 \mathrm{M}-\mathrm{Br}]^{+}$is sufficiently strong so that losses of $\mathrm{HBr}$ and $\mathrm{NH}_{3}$ occur in preference to the loss of a monomeric subunit. This type of neutral loss is likely only if the two monomeric subunits are covalently bound to each other. Further evidence that this complex is rather strongly bound can be found in the CID of each of the products after the $\mathrm{HBr}$ losses (Figure 3 and Table 1). The CID results in the production of $[2 \mathrm{M}-2 \mathrm{HBr}-\mathrm{Br}]^{+}$and $[2 \mathrm{M}-3 \mathrm{HBr}-$ $\mathrm{Br}]^{+}$, respectively.

The two primary CID pathways investigated in this report begin with complexes that are structurally different. The $[2 \mathrm{M}-2 \mathrm{HBr}-\mathrm{Br}]^{+}$complex at $m / z 408.7$ is the result of the loss of two molecules of $\mathrm{HBr}$. The [2M $\left.-2 \mathrm{HBr}-\mathrm{NH}_{3}-\mathrm{Br}\right]^{+}$complex at $m / z 391.7$ is the result of a loss of an $\mathrm{NH}_{3}$ and two $\mathrm{HBr}$ molecules. The $\mathrm{MS}^{\mathrm{n}}$ of both complexes ultimately yielded $\left[2 \mathrm{M}-\mathrm{CH}_{4} \mathrm{~N}-\right.$ $\left.\mathrm{CH}_{3} \mathrm{~N}-3 \mathrm{HBr}-\mathrm{Br}\right]^{+}$at $\mathrm{m} / z$ 269.7. This reinforces the idea that they have the same strongly bound core. A diagram of the $\mathrm{MS}^{\mathrm{n}}$ experiments is given in Figure 3. Clearly, the subsequent losses of $\mathrm{C}_{2} \mathrm{H}_{4} \mathrm{~N}$ and $\mathrm{C}_{2} \mathrm{H}_{3}$ indicate that the formation of a palladium-carbon bond with the ligand is not occurring.

The bonding in the $[2 \mathrm{M}-\mathrm{Br}]^{+}$has been shown to be strong enough for there to be a covalent interaction between the two monomers. The use of density functional theory calculations has made the assignment of a structure for the $[2 \mathrm{M}-\mathrm{Br}]^{+}$dimer possible (Figure 4). The dimer could be formed in solution from the reaction of the monomer $\mathrm{M}$ with either the $[\mathrm{M}-\mathrm{Br}]^{+}$or $[\mathrm{M}$ $\left.+\mathrm{H}_{2} \mathrm{O}-\mathrm{Br}\right]^{+}$cations. Calculated reaction enthalpies at $0 \mathrm{~K}$ reveal the two reactions to be exothermic (eq 1).

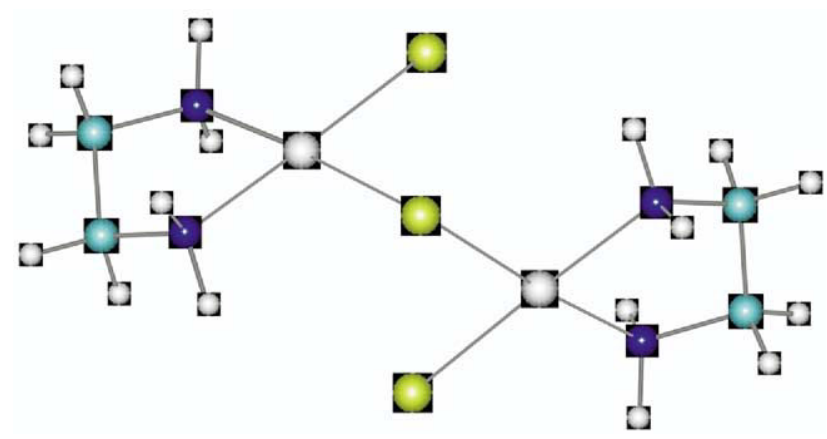

Figure 4. A minimum-energy structure for the $[2 \mathrm{M}-\mathrm{Br}]^{+}$cation optimized at the B3-LYP/SBKJC[d] level of theory. The structure possesses $C_{2}$ symmetry and is viewed down the rotational axis. 


$$
\begin{array}{r}
\mathrm{M}+[\mathrm{M}-\mathrm{Br}]^{+} \rightarrow[2 \mathrm{M}-\mathrm{Br}]^{+} \\
\Delta_{\mathrm{t}} \mathrm{H}_{0 \mathrm{k}}=-57.4 \mathrm{kcal} / \mathrm{mol} \\
\mathrm{M}+\left[\mathrm{M}+\mathrm{H}_{2} \mathrm{O}-\mathrm{Br}\right]^{+} \rightarrow[2 \mathrm{M}-\mathrm{Br}]^{+}+\mathrm{H}_{2} \mathrm{O} \\
\Delta_{\mathrm{t}} \mathrm{H}_{0 \mathrm{k}}=-25.6 \mathrm{kcal} / \mathrm{mol}
\end{array}
$$

These calculations are consistent with the results from the ESMS experiments (Table 1), where both the $[\mathrm{M}-\mathrm{Br}]^{+}$and $\left[\mathrm{M}+\mathrm{H}_{2} \mathrm{O}-\mathrm{Br}\right]^{+}$cations were observed. While the presence of the neutral monomer $\mathrm{M}$ cannot be directly determined using MS, its presence can be inferred from observation of the $[3 \mathrm{M}-\mathrm{Br}]^{+}$and $[2 \mathrm{M}+\mathrm{Na}]^{+}$species.

$\mathrm{Pd}(\mathrm{en}) \mathrm{Br}_{2}$ is expected to hydrolyze in an aqueous solution, producing mostly hydroxo and aqua complexes depending on $\mathrm{pH}$. This behavior is analogous to that of $\mathrm{Pd}(\mathrm{en}) \mathrm{Cl}_{2}$ [21]. At a concentration of $1 \mu \mathrm{M}$ and at $\mathrm{pH} 4.4$, the potentiometric studies show that $\mathrm{Pd}(\mathrm{en})\left(\mathrm{H}_{2} \mathrm{O}\right)_{2}{ }^{2+}$ is expected to be the only species present in solution $[18,34]$. In the mass spectrum shown in Figure 1, the only aqua species observed was the $\mathrm{Pd}(\mathrm{en})\left(\mathrm{H}_{2} \mathrm{O}\right) \mathrm{Br}^{+}$adduct at $m / z$ 262.9. A similar complex was also observed without water at $\mathrm{m} / \mathrm{z} 244.9$. It should be noted that there is little evidence of noncovalent clustering in the full scan mass spectrum of the $\mathrm{Pd}(\mathrm{en}) \mathrm{Br}_{2}$ solution because of the lack of complexes containing $\mathrm{H}_{2} \mathrm{O}$ and $\mathrm{H}^{+}$. Only one protonated complex $\left([\mathrm{M}+\mathrm{en}+\mathrm{H}]^{+}\right.$at $m / z$ 384.9) and the aqua complex ([M $\left.+\mathrm{H}_{2} \mathrm{O}-\mathrm{Br}\right]^{+}$at $m / z$ 262.9), mentioned above, have been observed. This would lead one to believe that the $\left[\mathrm{M}+\mathrm{H}_{2} \mathrm{O}-\mathrm{Br}\right]^{+}$complex is formed in solution, consistent with the poteniometric investigations [18], and is not an artifact of the ES process. Because aqueous $\mathrm{Pd}(\mathrm{en}) \mathrm{Br}_{2}$ is an equilibrium system, the types of species present in solution are very sensitive to both concentration and $\mathrm{pH}$. For example, $\mathrm{Pd}(\mathrm{en}) \mathrm{Cl}_{2},\left[\mathrm{Pd}(\mathrm{en})\left(\mathrm{H}_{2} \mathrm{O}\right) \mathrm{Cl}\right]^{+}$, and $\left[\mathrm{Pd}(\mathrm{en})\left(\mathrm{H}_{2} \mathrm{O}\right)_{2}\right]^{2+}$ have been determined to be in equilibrium in a $1 \mathrm{mM}$ solution of $\mathrm{Pd}(\mathrm{en}) \mathrm{Cl}_{2}$ at $\mathrm{pH} 4.4$. At $\mathrm{pH} 7$ in both $1 \mu \mathrm{M}$ and $1 \mathrm{mM}$ solutions, dimeric species of the type $\left[(\mathrm{en}) \mathrm{Pd}(\mu-\mathrm{OH})_{2} \mathrm{Pd}(\mathrm{en})\right]^{2+}$ have been reported in which the two $\mathrm{Pd}$ atoms are bridged by two hydoxo groups. This complex would occur at $m / z 183$. In the full mass spectrum, a set of peaks is observed at $\mathrm{m} / \mathrm{z} 183$ which can be attributed to a dication, but the peaks do not have enough intensity to resolve the isotopic pattern sufficiently to positively identify the complex.

We propose that the ions detected by ESMS are a consequence of a variety of processes occurring simultaneously. First, the observed results are due in part to the ligand exchange occurring in aqueous solution. Ligand exchange in solutions of inorganic coordination compounds is well known and has also been observed in ESMS experiments [42-44]. Second, the observed complexes may also be the result of concentration and $\mathrm{pH}$ effects taking place during the desolvation process. The formation of $\mathrm{Pd}(\mathrm{en})_{2}{ }^{2+}$ is, however, likely to occur in solution rather than in the ES desolvation process. The ES process takes a snapshot of the solution at the point when it is desolvated. During the electrospray desolvation process, ion-molecule and ion-ion interactions can occur [45]. As desolvation proceeds, both the concentrations of the $\mathrm{Pd}(\mathrm{II})$ species and $\mathrm{H}^{+}$increase. This may lead to the formation of species that cannot normally be observed in dilute aqueous solution. The observation of unexpected species at higher masses has been reported in a few other cases, and questions have been raised about their possible formation during the ES process $[33,42,46]$. Similar formations of dimers and trimers was reported by Sassi et al. in an ESMS study of monmeric $\mathrm{Pt}(\mathrm{II})$ amidines [28, 29], but no explanation for their formation was given. Since the maximum solubility of the $[\mathrm{Pd}(\mathrm{en})] \mathrm{X}_{2}(\mathrm{X}=\mathrm{Cl}$ or $\mathrm{Br})$ is about $10^{-2} \mathrm{M}$, desolvation during electrospray seems to provide a novel and unique method for investigating the species formed in very concentrated solution, that are well beyond the normal solubility of the compound.

\section{Conclusions}

We report the formation of a strongly bound dimeric complex from an aqueous solution of $\mathrm{Pd}(\mathrm{en}) \mathrm{Br}_{2}$. The results of numerous $\mathrm{MS}^{\mathrm{n}}$ experiments have yielded detailed insights into the strength and structure of this complex. The investigation of the aqueous complexes of dibromo(ethylenediamine)palladium(II) has revealed a rich and complicated aqueous chemistry, previously unreported. The electrospray process has played a crucial role in this study in terms of volatilizing the species in the aqueous solutions. Whether the electrospray process has also had a hand in creating some of the observed complexes remains to be explored. Deuterium studies are the next logical step to investigate the mechanistic details underlying the fragments observed here. The quadrupole ion-trap mass spectrometer has allowed the investigation of the structure of the [2M $\mathrm{Br}]^{+}$dimer because of the trap's ability to perform multiple MS steps. Further investigations are planned at lower $\mathrm{pH}$, where protonated and cationic species are expected, and at higher $\mathrm{pH}$, where anionic complexes might be observable. The neutrals, which are known to exist in this system, cannot be observed using ES. Thus, atmospheric pressure chemical ionization will be employed, as well as metal cation attachment. Further investigations are also planned employing cation and anion HPLC to determine the role that the electrospray process plays in the formation of these complexes.

\section{Acknowledgments}

This project was supported through a Departmental Welch Grant (AX-0026) from the Welch Foundation and the RISE (GM 60,655) and SCORE (GM 08,194) programs of the National Institutes of Health. GNM gratefully acknowledges computer time provided by the Bioinformatics Core Facility at the University of Texas Health Science Center at San Antonio. 


\section{References}

1. Colton, R.; D'Agostino, A.; Trager, J. C. Electrospray Mass Spectrometry Applied to Inorganic and Organometallic Chemistry. Mass Spectrom. Rev. 1995, 14, 79-106.

2. Henderson, W.; Nicholson, B. K.; McCaffrey, L. J. Applications of Electrospray Mass Spectrometry in Organometallic Chemistry. Polyhedron 1998, 17, 4291-4313.

3. Sheperd, R. E. Chromatographic and Related Electrophoretic Methods in the Separation of Transition Metal Complexes or Their Ligands. Coord. Chem. Rev. 2003, 247, 147-184.

4. Stewart, I. I.Electrospray Mass Spectrometry: A Tool for Elemental Speciation. Spectrochim. Acta Part B1999, 54, 16491695

5. Milovic, M. N.; Kostic, N. M. Palladium(II) Complexes as a Sequence-Specific Peptidase: Hydrolytic Cleavage Under Mild Conditions of X-Pro Peptide Bonds in X-Pro-Met and X-ProMet-His Segments. J. Am. Chem. Soc. 2003, 125, 781-788.

6. Zhu, L.; Kostic, N. M. Toward Artificial Metallopeptidases: Mechanisms by which Platinum(II) and Palladium(II) Complexes Promote Selective, Fast Hdyrolysis of Unactivated Amide Bonds in Peptides. Inorg. Chem. 1992, 31, 3944-4001.

7. Pettit, L. D.; Bezer, M. Complex Formation Between Palladium(II) and Amino Acids, Peptides, and Related Ligands. Coord. Chem. Rev. 1985, 61, 97-114.

8. Rosenberg, B.; Van Camp, L.; Trosko, J. R.; Mansour, V. A. Platinum Compounds: A New Class of Potent Antitumor Agents. Nature 1969, 222, 385.

9. Appleton, T. G.; Bailey, A. J.; Bedgood, J.; Danny, R.; Hall, J. R. Amino Acid Complexes of Palladium(II). 1. NMR Study of Reactions of the Diaqua(ethylenediamine) Palladium(II) Cation with Ammonia, Betaine, and the Amino Acids ${ }^{+} \mathrm{NH}_{3}\left(\mathrm{CH}_{2}\right)_{\mathrm{n}} \mathrm{CO}_{2}{ }^{+}(\mathrm{n}=1-3)$. Inorg. Chem. 1994, 33, 217-226.

10. Fuertes, M. A.; Alonso, C.; Perez, J. M. Biochemical Modulation of Cisplatin Mechanisms of Action: Enhancement of Antitumor Activity and Circumvention of Drug Resistance. Chem. Rev. 2003, 103, 645-662.

11. Kasparkova, J.; Zehnulova, J.; Farrell, N.; Brabec, V. DNA Interstrand Cross-Links of the Novel Antitumor Trinuclear Platinum Complex BBR3464. Conformation, Recognition by High Mobility Group Domain Proteins, and Nucleotide Excision Repair. J. Biol. Chem. 2002, 277, 48076-48086.

12. Freona, D.; Giovagnini, L.; Ronconi, L.; Marzano, C.; Trevisan, A.; Biondi, B.; Bordin, F. J. Pt(II) and Pd(II) Derivatives of Tert-Butylsarcosinedithiocarbabamate Synthesis, Chemical and Biological Characterization, and in vitro Nephrotoxicity. J. Inorg. Biochem. 2003, 93, 181-189.

13. Akbar Ali, M.; Mirza, A. H.; Butcher, R. J.; Tarafder, M. T. H.; Keat, T. B.; Manaf Ali, A. J. Biological Activity of Palladium(II) and Platinum(II) Complexes of the Acetone Schiff Bases SMethyl- and S-Benzyldithiocarbazate and the X-ray Crystal Structure of the [Pd(asme)2] (Asme=Anionic Form of the Acetone Schiff Base of S-Methyldithiocarbazate) Complex. J. Inorg. Biochem. 2002, 92, 141-148.

14. Matesanz, A. I.; Perez, J. M.; Navarro, P.; Moreno, J. M.; Colacio, E.; Souza, P. J. Synthesis and Characterization of Novel Palladium(II) Complexes of Bis(thiosemicarbazone). Structure, Cytotoxic Activity, and DNA Binding of (Pd(I)Benzyl Bis(thiosemicarbazonate). J. Inorg. Biochem. 1999, 76, 29-37.

15. Wyatt, K. S.; Harrison, K. N.; Jensen, C. M. Release of Platinum from Cysteine Residues Induced by N,S-Donor Chelation. Inorg. Chem. 1992, 31, 3867-3868.

16. Djuran, M. I.; Lempers, E. L. M.; Reedijk, J. Reactivity of Chloro- and Aqua(diethylenetriamine) Platinum(II) Ions with Glutathione, S-Methyleglutathione, and Guanosine 5'-Monophosphate in Relation to the Antitumor Activity and Toxicity of Platinum Complexes. Inorg. Chem. 1991, 30, 2648-2652.
17. Martin, R. B. Platinum Complexes: Hydrolysis and Binding to $\mathrm{N}(7)$ and N(1) of Purines. In Cisplatin: Chemistry and Biochemistry of a Leading Anticancer Drug; Lippert, B., Ed. Verlag Helvetica Chimica Acta: Zurich, Switzerland, 1999, pp 183205.

18. Tercero-Moreno, J. M.; Matilla-Hernandez, A.; Gonzales-Garcia, S.; Niclos-Gutierrez, J.Hydrolytic Species of the Ion Cis-Diaqua(ethylenediamine)Palladium(II) Complex and of Cis-dichloro(ethylenediamine) Palladium (II): Fitting Its Equilibrium Models in Aqueous Media With or Without Chloride Ion. Inorg. Chim. Acta 1996, 253, 23-29.

19. Giacomelli, A.; Malatesta, F.; Spinetti, M. C.Solution Reactions at Palladium(II) Complexes Producing Dimeric Species: Stability Constants Determination for Simultaneous Equilibria. Inorg. Chim. Acta 1981, 51, 55-60.

20. Anderegg, G. The Stability of the Palladium(II) Complexes with Ethylenediamine, Diethylenetriamine and Tris $(\beta$-aminoethyl)-Amine. Inorg. Chim. Acta 1986, 111, 25-30.

21. Tercero, J. M.; Matilla, A.; Sanjuan, M. A.; Moreno, C. F.; Martin, J. D.; Walmsley, J. A. Synthesis, Characterization, Solution Equilibria, and DNA Binding of Some Mixed-Ligand Palladium(II) Complexes. Thermodynamic Models for Carboplatin Drug and Analogous Compounds. Inorg. Chim. Acta. 2003, 342, 77-87.

22. Wee, S.; O'Hair, R. A. J.; McFadyen, W. D. Gas-Phase Ligand Loss and Ligand Substitution Reactions of Platinum(II) Complexes of Tridentate Nitrogen Donor Ligands. Rapid Commun. Mass Spectrom. 2004, 18, 1221-1226.

23. Tsierkezos, N. G.; Schröder, D.; Schwarz, H. Complexation of Nickel(II) by Ethylenediamine Investigated by Means of Electrospray Ionization Mass Spectrometry. Int. J. Mass Spectrom. 2004, 235, 33-42.

24. Styles, M. L.; O'Hair, R. A. J.; McFadyen, W. D.; Tannous, L.; Holmes, R. J.; Gable, R. W. Formation and Gas Phase Fragmentation Reactions of Ligand Substitution Products of Platinum(II) Complexes via Electrospray Ionization Tandem Mass Spectrometry. J. Chem. Soc. Dalton Trans. 2000, 93-99.

25. Holmes, R. J.; O'Hair, R. A. J.; McFadyen, W. D. Electrospray Ionization Tandem Mass Spectrometric Studies of Competitive Pyridine Loss from Platinum(II) Ethylenediamine Complexes by the Kinetic Method. Rapid Commun. Mass Spectrom. 2000, 14, 2385-2392.

26. Henderson, W.; Sabat, M. Platinum(II)- and Palladium(II)Amide Complexes [M $\left\{\mathrm{NC}(\mathrm{O}) \mathrm{CH}_{2} \mathrm{CH}_{2} \mathrm{CH}_{2}\right\}_{2} \mathrm{~L}_{2}$ ] Derived from 2-Azetidinone ( $\beta$-Propiolactam). A Synthetic, Electrospray Mass Spectrometric and X-ray Crystallographic Study. Polyhedron 1997, 16, 1663-1677.

27. Henderson, W.; Evans, C.Electrospray Mass Spectrometric Analysis of Transition-Metal Halide Complexes. Inorg. Chim. Acta 1999, 294, 183-192.

28. Michelin, R. A.; Bertani, R.; Mozzon, M.; Sassi, A.; Benetollo, F.; Bombieri, G.; Pombeiro, A. J. L. Cis Addition of Dimethylamine to the Coordinated Nitriles of cis- and trans$\left[\mathrm{PtCl}_{2}(\mathrm{NCMe})_{2}\right]$. X-ray Structure of the Amidine Complex cis- $\left[\mathrm{PtCl}_{2}\left\{E-\mathrm{N}(\mathrm{H})=\mathrm{C}\left(\mathrm{NMe}_{2}\right) \mathrm{Me}_{2}\right] \cdot \mathrm{CH}_{2} \mathrm{Cl}_{2}\right.$. Inorg. Chem. Commun. 2001, 4, 275-280.

29. Bertani, R.; Seraglia, R.; Favretto, D.; Michelin, R. A.; Mozzon, M.; Sbovata, S. M.; Sassi, A. Electrospray Mass Spectrometry of $\mathrm{Pt}(\mathrm{II})$ Amidine Complexes of the Type Cis- and Trans$\left[\mathrm{PtCl}_{2}\left\{\mathrm{NH}=\mathrm{C}(\mathrm{R}) \mathrm{NR}^{\prime} \mathrm{R}^{\prime \prime}\right\}_{2}\right]$ and Trans- $\left[\mathrm{PtCl}_{2}(\mathrm{RCN})\{\mathrm{NH}=\right.$ C(R)NR'R"'\}]. Inorg. Chem. Acta 2003, 356, 357-364.

30. Ehrsson, H. C.; Wallin, I. B.; Andersson, A. S.; Edlund, P. O. Cisplatin, Transplatin, and Their Hydrated Complexes: Separation and Identification Using Porous Graphitic Carbon and Electrospray Ionization Mass Spectrometry. Anal. Chem. 1995, $67,3608-3611$. 
31. Fisher, K. J.; Dance, I. G.; Willett, G. D.; Zhang, R.; Alyea, E.Electrospray Studies of a Water Soluble Platinum(II) Phoshine Complex, Chlorotris(1,3,5-triaza-7-phosphaadamantane)Platinum(II) Chloride (TPA) ${ }_{3} \mathrm{PtCl}_{2}$ ). Eur. J. Mass Spectrom. 2000, 6, 23-30.

32. Luo, X.; Huang, W.; Mei, Y; Zhou, S.; Zhu, L. Interaction of Palladium(II) Complexes with Sulfur-Containing Peptides Studied by Electrospray Mass Spectrometry. Inorg. Chem. 1999, $38,1474$.

33. Beck, J. L.; Humphries, A.; Sheil, M. M.; Ralph, S. F.Electrospray Ionization Mass Spectrometry of Ruthenium and Palladium Complexes with Oligonucleotides. Eur. Mass Spectrom.1999, 5, 489.

34. Nag, Z.; Sovago, I. Thermodynamic and Structural Characterization of the Complexes Formed in the Reaction of $\left[\mathrm{Pd}(\mathrm{en})\left(\mathrm{H}_{2} \mathrm{O}\right)_{2}\right]^{2+}$ and $\left[\mathrm{Pd}(\text { pic })\left(\mathrm{H}_{2} \mathrm{O}\right)_{2}\right]^{2+}$ with N-Alkyl Nucleobases and N-Acetyl Amino Acids. J. Chem. Soc. Dalton Trans. Inorg. Chem. 2001, 2467-2475.

35. McCormick, B. J.; Jaynes, E. N., Jr.; Kaplan, R. I. Dichloro (ethylenediamine)Palladium(II) and (2,2'-bipyridine)Dichloropalladium(II). Inorg. Synth. 1971, 13, 216-218.

36. Stephens, J. P.; Devlin, F. J.; Chabalowski, C. F.; Frisch, M. J. $\mathrm{Ab}$ Initio Calculations of Vibrational Absorption and Circular Dichroism Spectra Using Density Functional Force Fields. J. Phys. Chem. 1994, 98, 11623-11627.

37. Stevens, W. J.; Basch, H.; Krauss, M. J. Compact Effective Potentials and Efficient Shared-Exponent Basis Sets for the Firstand Second-Row Atoms. J. Chem. Phys. 1984, 81, 6026-6033.

38. Stevens, W. J.; Krauss, M. J.; Basch, H.; Jasien, P. G. Relativistic Compact Effective Potentials and Efficient, Shared-Exponent
Basis Sets for the Third-, Fourth-, and Fifth-Row Atoms. Can. J. Chem. 1992, 70, 612-630.

39. Cundri, T. R.; Stevens, W. J. Effective Core Potential Methods for the Lanthanides. J. Chem. Phys. 1993, 98, 5555-5565.

40. Hariharan, P. C.; Pople, J. A.The Influence of Polarization Functions on Molecular Orbital Hydrogenation Energies. Theor. Chim. Acta 1973, 28, 213-222.

41. Schmidt, M. W.; Baldridge, K. K.; Boatz, J. A.; Elbert, S. T.; Gordon, M. S.; Jensen, J. H.; Koseki, S.; Matsunaga, N.; Nguyen, K. A.; Su, S.; Windus, T. L.; Montgomery, J.; Dupuis, M. General Atomic and Molecular Electronic Structure System. J. Comput. Chem. 1993, 14, 1347-1363.

42. Gatlin, C. L.; Turecek, F. Electrospray Ionization of Inorganic and Organometallic Complexes. In Electrospray Ionization Mass Spectrometry; Cole, R. B., Ed.; Wiley and Sons: New York, NY, 1997, pp 527-570.

43. Cant, A. J.; Colton, R.An Electotrospray Mass Spectrometric Study of Methylmercury(II) Nitrogen Base Derivatives and Their Ligand Exchange Reactions. Inorg. Chim. Acta 1994, 215, 179-184.

44. Cardwell, T. J.; Colton, R.; Lambropoulos, N.; Traeger, J. C.Electrospray Mass Spectrometry of Zinc Dithiophosphate Derivatives and Its Application to the Analysis of Engine Oil Antiwear Derivatives. Anal. Chim. Acta 1993, 280, 239-244.

45. Gaskell, S. Electrospray: Principles and Practice. J. Mass Spectrom. 1997, 32, 677-688.

46. Wilson, S. R.; Wu, Y. A. Study of Nickel-Catalyzed Coupling Reactions by Electrospray Ionization Mass Spectrometry. Organometallics 1993, 12, 1478-1480. 